\title{
The Deficient Carbohydrate Metabolic Pathways and the In- complete Tricarboxylic Acid Cycle in an Obligately Autotrophic Hydrogen-oxidizing Bacterium
}

\author{
Hirotaka Shiba, Toshiyuki Kawasumi, Yasuo Igarashi, \\ Tohru Kodama and Yasuji Minoda \\ Department of Agricultural Chemistry, The University of Tokyo, \\ Bunkyo-ku, Tokyo 113, Japan \\ Received April 19, 1982
}

\begin{abstract}
The activities of enzymes of carbohydrate metabolism, enzymes of the tricarboxylic acid cycle and some related enzymes were measured in cell-free extracts of strain TK-6, an extremely thermophılic, obligately autotrophic, aerobic hydrogen-oxıdizing bacterıum. Activitıes of phosphofructokinase, aldolase, pyruvate kinase, 6-phosphogluconate dehydrase and 2-keto-3-deoxy-6phosphogluconate aldolase, key enzymes of the Embden-Meyerhof and the Entner-Doudoroff pathways were not found in the extracts. All of the tricarboxylic acid cycle enzymes except $\alpha$ ketoglutarate dehydrogenase, and reduced nicotinamide adenine dinucleotide oxidase were present. These metabolic defects are considered to be one of the reasons for the obligate autotrophy of strain TK-6.
\end{abstract}

In a previous paper, ${ }^{1)}$ we reported the isolation of an extremely thermophilic, aerobic, hydrogen-oxidizing bacterium from Miné hot spring, Izu Peninsula, Japan. This strain, TK6 , cannot utilize organic compounds as the sole source of carbon and energy for growth; it is an obligately autotrophic hydrogen bacterium. This is unique, since all the aerobic hydrogen-oxidizing bacteria previously described including the moderate thermophiles $^{2 \sim 4)}$ and the extreme thermophile, ${ }^{5,6}$ were facultative autotrophs which could grow heterotrophically utilizing organic compounds. ${ }^{7)}$ Obligate autotrophy was known ${ }^{8)}$ in the thiobacilli, the nitrifying bacteria and the blue-green algae but it was thought that there were no obligately autotrophic hydrogenoxidizing bacteria except Methanobacterium thermoautotrophicum, ${ }^{9)}$ an anaerobic, extremely thermophilic methanogenic bacterium.

Several explanations have been proposed as to why obligate autotrophs cannot use organic compounds. $^{8)}$ These include inhibition of growth by organic compounds, lack of transport for organic compounds, a block in the tricarboxylic acid cycle, an insufficient energy supply for growth from organic compounds and so on. But none of these are common to all obligate autotrophs. For example, it has been reported $^{10 \sim 13)}$ that cell-free extracts of many obligate autotrophs lack key enzymes of the Embden-Meyerhof pathway, enzymes of the Entner-Doudoroff pathway and $\alpha$-ketoglutarate dehydrogenase. However, there is an obligate autotroph which does have $\alpha$-ketoglutarate dehydrogenase. ${ }^{14)}$ Thus, the absence of this enzyme is not the only reason for the inability to utilize organic compounds. The aim of this work was to determine why strain TK-6 could not generate energy for growth from organic compounds. This was done by measuring the enzyme activities of central carbon metabolic pathways, i.e., of carbohydrate metabolism and the tricarboxylic acid cycle.

\section{MATERIALS AND METHODS}

Organism. The extremely thermophilic hydrogenoxidizıng bacterium, strain TK- $6,{ }^{1)}$ was isolated at Miné hot spring, Izu Peninsula, Shizuoka, Japan. 
Cultivation of strain TK-6. Strain TK-6 was cultivated in the inorganic medium previously described. ${ }^{1)}$ The inoculum was grown in $500 \mathrm{ml}$ shaking flasks containing $50 \mathrm{ml}$ medium and a mixture of gases $\left(\mathrm{H}_{2}-\mathrm{O}_{2}-\mathrm{CO}_{2}=\right.$ $75: 15: 10)$. The flasks were shaken on a reciprocating shaker for $16 \sim 20 \mathrm{hr}$ before transfer to a 2 liter jar fermentor (Labotec Co., Tokyo, Japan) containing 1 liter medium. The fermentor was continuously stirred at 1300 $\mathrm{rpm}$ and initially gassed with $600 \mathrm{ml} / \mathrm{min}$ of a gas mixture $\left(\mathrm{H}_{2}-\mathrm{CO}_{2}\right.$-air $\left.=13: 2: 5\right)$. After cultivation for $4 \mathrm{hr}$, oxygen was gradually introduced in a stepwise fashion from 5 to $20 \%$ of the total gas volume $(600 \sim 1000 \mathrm{ml} / \mathrm{min})$. The $\mathrm{pH}$ was controlled at 7.0 by addition of $\mathrm{NH}_{4} \mathrm{OH}$. The inoculum size was $25 \%$ and the cultivation temperature was $70^{\circ} \mathrm{C}$.

The cells were harvested in the late exponential phase by centrifugation and washed twice in $67 \mathrm{~mm}$ phosphate buffer, $\mathrm{pH} 7.0$, before resuspension in the same buffer.

Preparation of cell-free extracts. The cell suspensions of strain TK-6 were passed through a French pressure cell (Aminco Co., USA) at $1000 \mathrm{~kg} / \mathrm{cm}^{2}$ and sonicated (Kubota Co., Japan) at $100 \mathrm{~W}$ for $20 \mathrm{sec}$. The ruptured cells were centrifuged at $10,000 \times g$ for $20 \mathrm{~min}$ at $4^{\circ} \mathrm{C}$ and the supernatants were used as cell-free extracts for enzyme assays.

Enzyme assays. Enzyme activities were assayed spectrophotometrically with a Hitachi 200-10 type recording spectrophotometer using the following published methods: hexokinase, ${ }^{15)}$ glucosephosphate isomerase,${ }^{16)}$ phosphofructokinase, ${ }^{17)}$ aldolase, ${ }^{18)}$ triosephosphate isomerase ${ }^{19)}$ glyceraldehyde-phosphate dehydrogenase ${ }^{20)}$ phosphoglycerate kinase $^{20)}$ phosphoglyceromutase, ${ }^{21)}$ enolase, ${ }^{20)}$ pyruvate kinase $^{22)}$ lactate dehydrogenase, ${ }^{23)}$ glucose-6-phosphate dehydrogenase (NADP), ${ }^{24)}$ 6phosphogluconate dehydrogenase (NADP) ${ }^{25)}$ citrate synthase, ${ }^{26)}$ aconitase, ${ }^{27)}$ isocitrate dehydrogenase (NAD and NADP) ${ }^{28)}$ succinyl-CoA synthetase,${ }^{29)}$ fumarase, ${ }^{30)} \mathrm{ma}$ late dehydrogenase, ${ }^{31)}$ isocitrate lyase, ${ }^{32)}$ malate synthase $^{33)}$ and $\mathrm{NAD}(\mathrm{P}) \mathrm{H}$ oxidase. ${ }^{10)}$ In addition, succinate dehydrogenase was measured by the method of Massey ${ }^{34)}$ using phenazine methosulfate and cytochrome $c ; \alpha$-ketoglutarate dehydrogenase and pyruvate dehydrogenase were measured by the method of Reed and Mukherjee ${ }^{35}$ ) and also by the method of Amarasingham and Davis ${ }^{36}$ using 3-acetylpyridine NAD.

For the enzymes, 6-phosphogluconate dehydrase and 2keto-3-deoxy-6-phosphogluconate (KDPG) aldolase, of the Entner-Doudoroff pathway, a coupled assay was used excluding KDPG aldolase from the assay reagents for 6phosphogluconate dehydrase. ${ }^{37)}$

All enzyme reactions were carried out at $30^{\circ} \mathrm{C}$, but enzymes of the tricarboxylic acid cycle and some related enzymes were also assayed at $50^{\circ} \mathrm{C}$ and $70^{\circ} \mathrm{C}$. Specific activities were defined as nanomoles substrate converted per min per mg of protein, and the protein concentration was determined by the method of Lowry et al. ${ }^{38)}$ using bovine serum albumin as a standard.

Chemicals. All chemicals were obtained from commercial sources and were of the highest purity available. All special reagents were purchased from Sigma Chemical Co., St. Louis, USA, except for enolase from Oriental Yeast Co., Ltd., Tokyo, Japan, and cocarboxylase from Nakarai Chemicals Ltd., Kyoto, Japan.

\section{RESULTS AND DISCUSSION}

\section{Enzymes of carbohydrate metabolism}

Assays for enzymes of carbohydrate metabolism were carried out at $30^{\circ} \mathrm{C}$, since commercial enzymes used as coupling reagents were inactivated rapidly at high temperature. The effectiveness of the enzyme assay methods was confirmed by use of cell-free extracts of Escherichia coli K 12 IAM 1264 for the Embden-Meyerhof pathway and the pentosephosphate pathway, and of Pseudomonas putida ATCC 12633 for the Entner-Doudoroff pathway. As shown in Table I, several enzymes of the Embden-Meyerhof pathway were present in cell-free extracts of strain TK-6. These enzyme activities were low compared with those of the extreme thermophile, Thermus

TAble I. SPecific Activities of Enzymes of Carbohydrate Metabolism in Cell-FreE EXTRACTS OF TK-6
Enzyme

Specific activity (nmol/min/mg of Protein)

\section{Hexokinase}

Glucosephosphate isomerase

Phosphofructokinase

Aldolase

Triosephosphate isomerase

Glyceraldehyde-phosphate dehydrogenase

Phosphoglycerate kinase

Phosphoglyceromutase

Enolase

Pyruvate kinase

Lactate dehydrogenase

Glucose-6-phosphate

dehydrogenase

6-Phosphogluconate dehydrogenase

6-Phosphogluconate dehydrase + KDPG aldolase
0.4

14.6

N.D.*

N.D.

512

87.2

47.6

10.1

13.2

N.D.

N.D.

5.6

N.D.
* N.D. $=$ not detected. 
thermophilus, measured at $25^{\circ} \mathrm{C} .{ }^{39)}$ Activities of phosphofructokinase, aldolase, pyruvate kinase and lactate dehydrogenase were not detected.

Key enzymes of the pentose-phosphate pathway, glucose-6-phosphate dehydrogenase and 6-phosphogluconate dehydrogenase, were present in cell-free extracts of TK-6 but their activities were very low. Two enzymes of the Entner-Doudoroff pathway, 6-phosphogluconate dehydrase and KDPG aldolase, assayed together in a coupled reaction, were not detected.

The above features are similar to those of obligate chemolithotrophs deficient in key enzymes of the Embden-Meyerhof and the Entner-Doudoroff pathways. ${ }^{40)}$ For example, phosphofructokinase, 6-phosphogluconate dehydrase and KDPG aldolase are also lacking from cell-free extracts of some nitrifying bacteria and thiobacilli. In this work, most enzyme activities in carbohydrate metabolism were assayed by the measurement of the decrease in NADH. So, weak enzyme activities might be hard to detect because of high NADH oxidase activity in cell-free extracts of TK-6. And it must be also kept in mind that enzyme activities were measured at $30^{\circ} \mathrm{C}$ rather than at the optimum for growth. Consequently, it cannot be confirmed that these enzyme activities are lacking altogether. However, it can be said that they are sufficiently weak to prevent TK-6 from generating enough energy for growth by catabolizing sugars.

Enzymes of the tricarboxylic acid cycle and some related enzymes

Table II shows that activities for all enzymes of the tricarboxylic acid cycle except $\alpha$-ketoglutarate dehydrogenase, were present in cellfree extracts of TK-6. This is similar to in many obligate autotrophs. In addition, pyruvate dehydrogenase activity also was not found. These activities were found to be absent on using both the $\mathrm{NAD}^{35}$ ) and 3-acetylpyridine $\mathrm{NAD}^{36)}$ assay methods at several temperatures from $30^{\circ} \mathrm{C}$ to $70^{\circ} \mathrm{C}$ while they were clearly present in cell-free extracts of $E$. coli and other microorganisms tested. In TK-6, activities of enzymes of the glyoxylic acid cycle were also lacking. All this indicates that the tricarboxylic acid cycle is incomplete and that the enzymes are part of a branching biosynthetic system.

Malate dehydrogenase activity was present

Table II. Specific Activities of Enzymes of the Tricarboxylic AcID Cycle and Some Related Enzymes in Cell-free Extracts of TK-6

\begin{tabular}{|c|c|c|c|}
\hline \multirow{2}{*}{ Enzyme } & \multicolumn{3}{|c|}{$\begin{array}{c}\text { Specific activity } \\
(\mathrm{nmol} / \mathrm{min} / \mathrm{mg} \text { of protein })\end{array}$} \\
\hline & $30^{\circ} \mathrm{C}$ & $50^{\circ} \mathrm{C}$ & $70^{\circ} \mathrm{C}$ \\
\hline Citrate synthase & 1.0 & 1.3 & 4.2 \\
\hline Aconitase & 20.3 & 54.5 & 24.8 \\
\hline Isocitrate dehydrogenase (NAD) & Trace & 4.6 & 19.1 \\
\hline Isocitrate dehydrogenase (NADP) & Trace & 2.4 & 2.3 \\
\hline$\alpha$-ketoglutarate dehydrogenase & N.D.* & N.D. & N.D. \\
\hline Succinyl-CoA synthetase & 83.6 & 208 & 372 \\
\hline Succinate dehydrogenase & 5.6 & 12.0 & \\
\hline Fumarase & 2.4 & 16.1 & 43.3 \\
\hline Malate dehydrogenase & 309 & 1270 & 3660 \\
\hline Pyruvate dehydrogenase & N.D. & N.D. & N.D. \\
\hline Isocitrate lyase & N.D. & & \\
\hline Malate synthase & N.D. & & \\
\hline NADH oxidase & 4.7 & 13.6 & \\
\hline NADPH oxidase & 1.6 & 7.4 & \\
\hline
\end{tabular}

$* \quad$ N.D. $=$ not detected. 
at a high level, similar to in the facultatively autotrophic hydrogen bacterium, Alcaligenes eutrophus (Hydrogenomonas eutropha). ${ }^{41)}$

As pyruvate dehydrogenase was not detected, there was no enzyme activity to connect the Embden-Meyerhof pathway with the tricarboxylic acid cycle. Because of the high activity of NADH oxidase, the activities of phosphoenolpyruvate carboxylase, phosphoenolpyruvate carboxykinase and pyruvate carboxylase could not be measured spectrophotometrically. These enzyme activities should be measured using radioisotope techniques.

To obtain fuller details of obligate autotrophy in strain TK-6, further work is needed. Investigations are underway to reveal the mechanisms for synthesis of cell materials from $\mathrm{CO}_{2}$ and for the production of energy from hydrogen.

Acknowledgment. This research was supported in part by a Grant-in-Aid for Scientific Research (No. 00548041) from the Ministry of Education, Science and Culture of Japan.

\section{REFERENCES}

1) T. Kawasumi, Y. Igarashi, T. Kodama and Y. Minoda, Agric. Biol. Chem., 44, 1985 (1980).

2) J. M. McGee, L. R. Brown and R. G. Tischer, Nature, 214, 715 (1967).

3) E. E. Emnova and G. A. Zavarzin, Mikrobiologiya, 46, 405 (1977).

4) E. Goto, T. Kodama and Y. Minoda, Agric. Biol. Chem., 42, 1305 (1978).

5) M. Aragno, FEMS Microbiol. Lett., 3, 13 (1978).

6) A. Schenk and M. Aragno, J. Gen. Microbiol., 115, 333 (1979).

7) B. Bowien and H. G. Schlegel, Ann. Rev. Microbiol., 35, 405 (1981).

8) A. J. Smith and D. S. Hoare, Bacteriol. Rev., 41, 419 (1977).

9) J. G. Zeikus and R. S. Wolfe, J. Bacteriol., 109, 707 (1972).

10) A. J. Smith, J. London and R. Y. Stanier, J. Bacteriol., 94, 972 (1967).

11) E. J. Johnson and S. Abraham, J. Bacteriol., 100, 962 (1969).

12) B. F. Taylor and D. S. Hoare, Arch. Mikrobiol., 80, 262 (1971).

13) R. A. D. Williams and D. S. Hoare, J. Gen. Microbiol., 70, 555 (1972).
14) P. J. leB. Williams and S. W. Watson, J. Bacteriol., 96, 1640 (1968).

15) M. D. Joshi and V. Jagannathan, "Methods in Enzymology," Vol. 9, ed. by W. A. Wood, Academic Press Inc., New York, 1966, p. 371.

16) E. A. Noltmann, "Methods in Enzymology," Vol. 9, ed. by W. A. Wood, Academic Press Inc., New York, 1966, p. 557.

17) V. F. Kemerer, C. C. Griffin and L. Brand, "Methods in Enzymology," Vol. 42, ed. by W. A. Wood, Academic Press Inc., New York, 1975, p. 91.

18) W. J. Rutter, J. R. Hunsley, W. E. Groves, J. Calder, T. V. Rjkumar and B. M. Woodfin, "Methods in Enzymology," Vol. 9, ed. by W. A. Wood, Academic Press Inc., New York, 1966, p. 479.

19) W. K. G. Krietsch, "Methods in Enzymology," Vol. 41, ed. by W. A. Wood, Academic Press Inc., New York, 1975, p. 434.

20) Y. Kagawa, "Seikagaku Jikken Koza," Vol. 12, ed. by the Japan Biochemical Society, Tokyo Kagaku Dojin Co. Ltd., Tokyo, 1976, p. 126.

21) G. D'Alessio and J. Josse, "Methods in Enzymology," Vol. 42, ed. by W. A. Wood, Academic Press Inc., New York, 1975, p. 139.

22) T. Bücher and G. Pfleiderer, "Methods in Enzymology," Vol. 1, ed. by S. P. Colowick and N. O. Kaplan, Academic Press Inc., New York, 1955, p. 435.

23) A. Yoshida and E. Freese, "Methods in Enzymology," Vol. 41, ed. by W. A. Wood, Academic Press Inc., New York, 1975, p. 304.

24) R. G. Langdon, "Methods in Enzymology," Vol. 9, ed. by W. A. Wood, Academic Press Inc., New York, 1966, p. 126.

25) S. Pontremoli and E. Grazi, "Methods in Enzymology," Vol. 9, ed. by W. A. Wood, Academic Press Inc., New York, 1966, p. 137.

26) P. D. J. Weitzman, "Methods in Enzymology," Vol. 13, ed. by J. M. Lowenstein, Academic Press Inc., New York, 1969, p. 22.

27) B. Fansler and J. M. Lowenstein, "Methods in Enzymology," Vol. 13, ed. by J. M. Lowenstein, Academic Press Inc., New York, 1969, p. 26.

28) W. W. Cleland, V. W. Thompson and R. E. Barden, "Methods in Enzymology," Vol. 13, ed. by J. M. Lowenstein, Academic Press Inc., New York, 1969, p. 30 .

29) W. A. Bridger, R. F. Ramaley and P. D. Boyer, "Methods in Enzymology," Vol. 13, ed. by J. M. Lowenstein, Academic Press Inc., New York, 1969, p. 70 .

30) R. L. Hill and R. A. Bradshaw, "Methods in Enzymology," Vol. 13, ed. by J. M. Lowenstein, Academic Press Inc., New York, 1969, p. 91.

31) G. B. Kitto, "Methods in Enzymology," Vol. 13, ed. by J. M. Lowenstein, Academic Press Inc., New York, 1969, p. 106. 
32) G. H. Dixon and H. L. Kornberg, Biochem. J., 72, 3P (1959).

33) G. H. Dixon and H. L. Kornberg, "Methods in Enzymology," Vol. 5, ed. by S. P. Colowick and N. O. Kaplan, Academic Press Inc., New York, 1965, p. 633.

34) V. Massey, Biochim. Biophys. Acta, 34, 255 (1959).

35) L. J. Reed and B. B. Mukherjee, "Methods in Enzymology," Vol. 13, ed. by J. M. Lowenstein, Academic Press Inc., New York, 1969, p. 55.

36) C. R. Amarsingham and B. D. Davis, J. Biol. Chem.,
240, 3664 (1965).

37) H. P. Meloche and W. A. Wood, "Methods in Enzymology," Vol. 9, ed. by W. A. Wood, Academic Press Inc., New York, 1966, p. 653.

38) O. H. Lowry, N. J. Rosebrough, A. L. Farr and R. J. Randall, J. Biol. Chem., 193, 265 (1951).

39) F. Yoshizaki and K. Imahori, Agric. Biol. Chem., 43, 537 (1979).

40) A. Matin, Ann. Rev. Microbiol., 32, 433 (1978).

41) H. G. Trüper, Biochim. Biophys. Acta, 111, 565 (1965). 